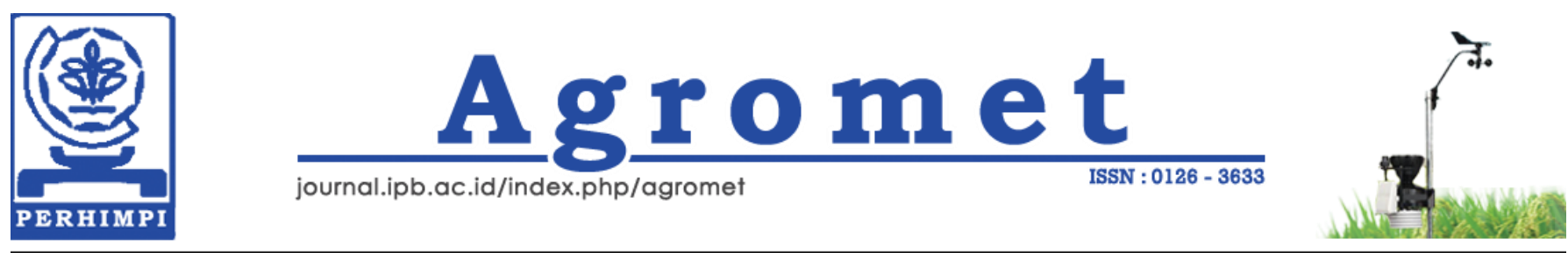

\title{
The Potency of the Rice Crop Index Development through Adjustment of Agroclimate and Water Management Situated in Rainfed Field Gunungkidul
}

\section{Eko Srihartanto and Sugeng Widodo}

Assessment Institutes for Agricultural Technology of Yogyakarta, Jl. Stadion Maguwoharjo 22, Wedomartani, Ngemplak, Sleman, Daerah Istimewa Yogyakarta, Indonesia 55584

\section{ARTICLE INFO}

\section{Received}

30 October 2019

\section{Revised}

4 April 2020

\section{Accepted for Publication}

3 June 2020

\section{Published}

9 September 2020

doi: 10.29244/j.agromet.34.2.75-88

\section{Correspondence: \\ Eko Srihartanto \\ Assessment Institutes for Agricultural \\ Technology of Yogyakarta Indonesian Agency for Agricultural Research and Development Ministry of Agriculture, J. Stadion Maguwoharjo 22, Wedomartani, Ngemplak, Sleman, D.I.Yogyakarta. \\ Email: srihartantoeko@yahoo.co.id}

This is an open-access article distributed under the CC BY License. (c) 2020 The Authors. Agromet.

\section{A B S T R A C T}

One of the strategies to increase the rice self-sufficiency is by improving the rice crop index (IP) in rainfed field areas. This paper aims to obtain the areas for IP development based on agroclimate information on the rainfed fields in Gunungkidul. The methodology of research was based on descriptive analysis, surveys and interviews involving farmers, researchers, agricultural officers, and village officials. We performed field surveys and interviews in 2016 and 2017. The surveys were carried out by identification and verification of the water sources for agriculture, determination of the appropriate water infrastructure, and determination of the areas affected by rice cultivation development. The results showed that the determination of the beginning of planting season could refer the Modern Integrated Planting Calendar (KATAM) and the estimation of the start of the rainy season by the local meteorological office (BMKG). We estimated that as many of 2,111 ha was suitable for IP 200 development, which may raise the potency of rice production to 10,058 tons (increased by 5.10\%). On other hand, the IP 300 only covers the rainfed field areas of 687 ha, which has a potential rice production of 3,294 tons (increased by $1.67 \%$ ). Further identification and verification are needed regarding the potency of water sources. This will determine which types of proper water infrastructure that must be provided for support the development of IP, hence the national rice self-sufficiency.

\section{KEYWORDS}

Cropping pattern, descriptive analysis, IP 200, planting season, water infrastructure

\section{INTRODUCTION}

To achieve the rice self-sufficiency, the Government of Indonesia had launched a program call "increasing national rice production" in the period 20082013. Then, the government continued the program by introducing special effort to achieve self-sufficiency in rice, corn, and soybean (in Indonesia the program is called as UPSUS Pajale) in the 2014-2019 period. This effort was carried out by optimizing the use of sitespecific rice fields based on their agroecosystem conditions and supported by the use of land and water resources. Technological innovations were introduced by an improvement on cultivation techniques such as the use of adaptive superior varieties, rotation of varieties, integrated crop management, and cropping patterns based on water availability (Bhatta et al., 2017; Bravo-Ureta et al., 2020; Dahal et al., 2018; Faisal et al., 2019; Flor et al., 2016; Gremmen et al., 2019).

However, in some areas in Indonesia still apply a traditional cropping system such as in Yogyakarta Province. In this province, productivity of rice still relatively low (6.1 tons ha ${ }^{-1}$ for paddy field and 4.1 tons ha- ${ }^{-1}$ for rainfed field), while one study revealed a higher number of rice productivity about 7 tons ha-1 (Jamil et al., 2016). The low rice productivity was indicated by the value of 
the rice crop index (IP) of 100, although the potency for irrigated and rainfed rice fields is quite large about 55,292 ha and 185,821 ha (BPS-DIY, 2017). Another factor affecting low rice productivity is a relatively low land fertility, especially on rainfed field (Ikeura et al., 2019; Supriyadi et al., 2018). To increase rice productivity on rainfed field, several approaches had been introduced including the use of superior seeds and the latest processing technology (Valarmathi et al., 2019; Zeng et al., 2017), and improving water infrastructure (Materu et al., 2018; Tanko et al., 2019).

Technological innovations based on site-specific by building water infrastructure are needed to effectively increase the rice productivity and farmers' income. Technological innovations applied in rainfed field farming include (Boonlertnirun et al., 2017; Hongxing et al., 2017): (i) short-lived varieties for rainwater efficiency, and an effective and optimal planting patterns within a year; (ii) varieties with fluffier and delicious rice according to the appetite of the farming community, (iii) varieties that are resistant to pests and diseases, and (iv) varieties with high productivity yields.

Nowadays, farmers in Gunungkidul have practiced once cropping system (IP 100), which is not optimal for rice productivity as well as the farmers' income. To increase the optimal conditions, large area of rainfed field is required, that is barely applied. Therefore, the introduction of technological innovations that can increase the value of rice IP from 100 to 200, and IP 200 to 300 in rainfed field is required.

Efforts to increase rice production and productivity, especially in rainfed field, have been continued in order to support food security and food self-sufficiency. But there are food problems that are generally faced by the community, among others: (i) increasing food demand (Budhi et al., 2017; Kathpalia et al., 2018), (ii) land use change from agriculture to non-agriculture (Kumar et al., 2017, 2018), (iii) the impact of climate change on the agricultural sector (Boonwichai et al., 2019; Estiningtyas et al., 2009; Lv et al., 2018; Mulyaqin, 2020; Surmaini et al., 2018), and (iv) low interest of young generation working in agriculture sector (Adamowicz and Szepeluk, 2016; Anwarudin et al., 2018; May et al., 2019).

This research applied the potency of IP development to support an increased rice production without additional new land. Climate change adaptation measurement in the agricultural sector especially in rainfed field is important. Therefore, information on the potential development of rice IP through climate and water management in rainfed land in Gunungkidul is needed to support climate change adaptation.

\section{RESEARCH METHODS}

This study used two approaches namely surveysinterviews and descriptive analysis. Field surveys were conducted in two years (2016-2017) in Gunungkidul Regency. Participants of the survey consist of field officers (PPL), village officials, farmers, farmer groups, and related stakeholders. Information on (i) location identity (name of farmer group, name of a leader, mobile number, coordinates, hamlet, village, sub-district, and province); (ii) type of land, (iii) rice crop index (existing, targeted), (iv) rice productivity, (v) proposed building type, (vi) area of service affected, (vii) nearest water source (type, distance to land, and land height difference), (viii) number of water sources, (ix) supporting information, and $(x)$ documentation in the form of photos using the open camera application. Furthermore, the data were summarized and analysed to obtain the IP development potential and water infrastructures needed at the location. Microsoft Excel 2013 was used to data analysis and processing.

The second approach was descriptive analysis. This approach used literature review to obtain appropriate supporting data such as topographic, soil, and agroclimate zoning. The data then were processed to obtain the information on the cultivation technical strategy to support production and IP of rainfed field. Rainfall data from the local meteorological office (BMKG) were used to support descriptive precipitation analysis.

\section{Topographical Characteristics of Gunungkidul Region}

Gunungkidul Regency covers about $1,485 \mathrm{~km}^{2}$. It is about $47 \%$ of the total area of DI Yogyakarta Province. Based on BPS-Gunungkidul (2017), there were 18 sub-districts and 144 villages in Gunungkidul Regency. The regency is divided into three zones based on topographic, morphological, and hydrological characteristics, namely the northern zone (Great Batur Zone), the middle zone (Ledok Wonosari Zone), and the southern zone (Sewu Mountain Zone) (Table 1).

The first zone is The Batur Agung Zone. It is characterized by mountainous topography on the north and steep slopes on the west. In the Batur Agung zone, all types of perennial and food crops are able to grow because of plenty water availability. However, there is a small paddy field which is applied IP150-250 using irrigation with a supply of well irrigation water, springs, and rivers. Spatially, this zone covers Patuk, Nglipar, Gedangsari, Ngawen, Semin, and northern part of Ponjong. The second zone is Wonokari Ledok Zone. It is in the central area of Gunungkidul Regency with a flat to slightly undulating topography, which has a relatively thick layer of soil with better fertility compare 
Table 1. Topographical characteristics of Gunungkidul Region (Soerono, 2008)

\begin{tabular}{|c|c|c|c|c|c|c|}
\hline $\begin{array}{l}\text { Gunungkidul } \\
\text { area zone }\end{array}$ & $\begin{array}{l}\text { Altitude } \\
\text { (m) }\end{array}$ & Topography & $\begin{array}{l}\text { Diversity of } \\
\text { soil types }\end{array}$ & $\begin{array}{l}\text { State of surface } \\
\text { and ground } \\
\text { water resources }\end{array}$ & $\begin{array}{l}\text { Plant vegetation } \\
\text { diversity }\end{array}$ & Disaster hazard \\
\hline $\begin{array}{l}\text { North Zone } \\
\text { (Batur Agung } \\
\text { Zone) }\end{array}$ & $200-700$ & $\begin{array}{l}\text { Mountai- } \\
\text { nous }\end{array}$ & $\begin{array}{l}\text { Volcanic } \\
\text { Laterite, parent } \\
\text { rock Dasiet } \\
\text { and Andesite, } \\
\text { Entisol, Alfisol, } \\
\text { Inceptisol, } \\
\text { Oxisol, Vertisol }\end{array}$ & $\begin{array}{l}\text { There is the Oya } \\
\text { river, flowing } \\
\text { throughout the } \\
\text { year, with a } \\
\text { groundwater } \\
\text { depth of } 6-12 \\
\text { meters }\end{array}$ & $\begin{array}{l}\text { Perennial crops } \\
\text { (fruit and } \\
\text { wood) and } \\
\text { seasonal crops } \\
\text { (rice, secondary } \\
\text { crops, and } \\
\text { vegetables) }\end{array}$ & $\begin{array}{l}\text { Landslide, river } \\
\text { flooding } \\
\text { inundation, and } \\
\text { drought }\end{array}$ \\
\hline $\begin{array}{l}\text { Middle Zone } \\
\text { (Ledok } \\
\text { Wonosari) }\end{array}$ & $150-200$ & $\begin{array}{l}\text { Flat to } \\
\text { slightly } \\
\text { bumpy }\end{array}$ & $\begin{array}{l}\text { Inceptisol, } \\
\text { Vertisol, } \\
\text { Entisol, Oxisol, } \\
\text { Alfisol }\end{array}$ & $\begin{array}{l}\text { There are rivers, } \\
\text { dry conditions } \\
\text { during the dry } \\
\text { season, ground- } \\
\text { water depth of } 5 \\
-25 \mathrm{~m}\end{array}$ & $\begin{array}{l}\text { Perennial crops } \\
\text { (fruit and } \\
\text { wood) and } \\
\text { seasonal crops } \\
\text { (rice, secondary } \\
\text { crops, } \\
\text { vegetables) }\end{array}$ & $\begin{array}{l}\text { River flooding } \\
\text { inundation and } \\
\text { drought }\end{array}$ \\
\hline $\begin{array}{l}\text { South Zone } \\
\text { (Gunung } \\
\text { Sewu Zone) }\end{array}$ & $100-300$ & Hilly & $\begin{array}{l}\text { Lime soil } \\
\text { dominance. } \\
\text { Alfisol, Entisol, } \\
\text { Inceptisol, } \\
\text { Oxisol }\end{array}$ & $\begin{array}{l}\text { River on the } \\
\text { surface is small } \\
\text { and dry during } \\
\text { the dry season, } \\
\text { there are many } \\
\text { caves (luweng). } \\
\text { Depth of ground } \\
\text { water } 60-120 \mathrm{~m} \text {. }\end{array}$ & $\begin{array}{l}\text { Perennial crops } \\
\text { (fruit and } \\
\text { wood) and } \\
\text { seasonal crops } \\
\text { (upland rice } \\
\text { and secondary } \\
\text { crops) }\end{array}$ & Drought \\
\hline
\end{tabular}

with other zones. There were paddy fields which is applied IP250-300 using water supply from bore wells, water springs and rivers. This zone covers area of Playen, Wonosari, Karangmojo, central Ponjong, and northern Semanu. The third zone is Gunung Sewu. Gunung Sewuzone is in the southern region of
Gunungkidul Regency, with hilly topography leaving no terrain with a relatively narrow area. The dominance of dry land moor with thin soil solum and nutrient-poor, so that productivity is relatively low. This condition makes it difficult for residents to develop agribusiness activities. Barely any water sources have been found in

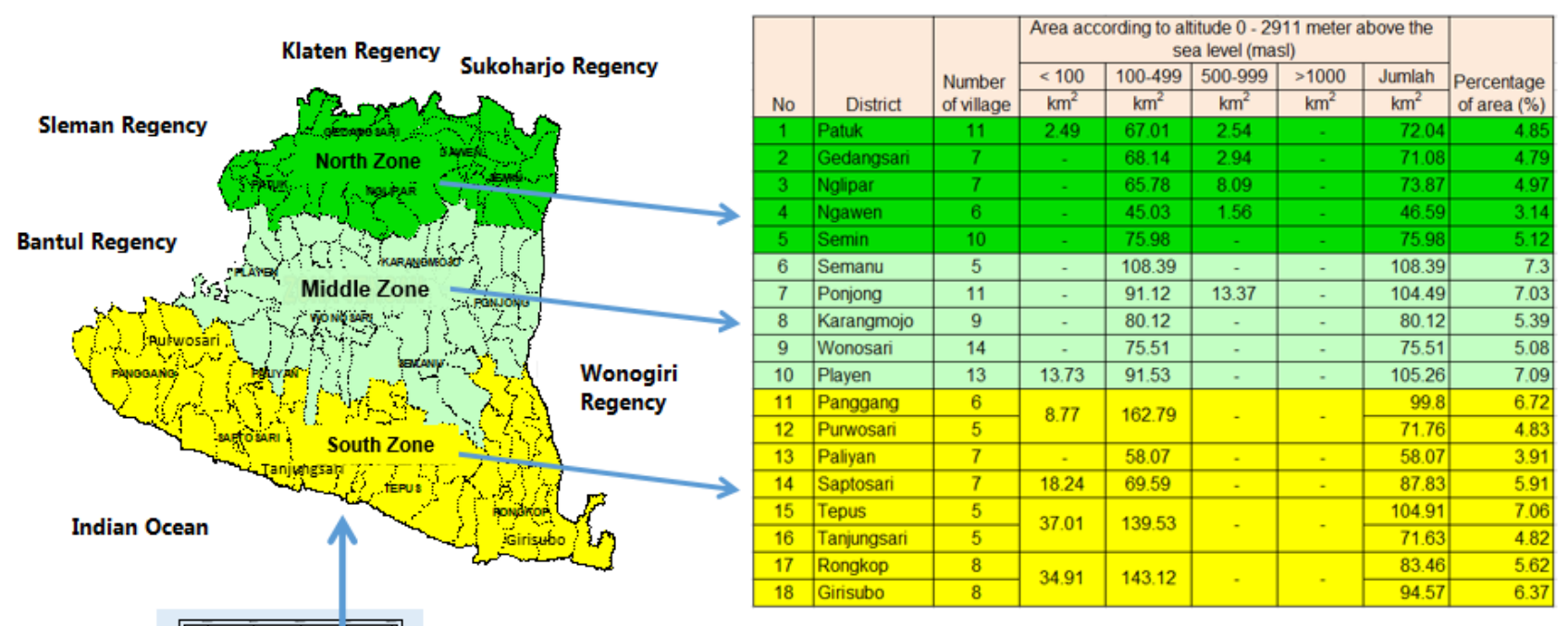


this zone, which is impossible to develop IP300. This zone is often experienced with drought disasters annually. Administratively, this zone covers Panggang, Paliyan, Tepus, Saptosari, Rongkop, Semanu southern, and southern Ponjong Sub-districts. The administrative area (Sub-district) and topographical zoning of the Gunungkidul area in each zone is shown in Figure 1.

\section{Characteristics of Soil and Agroclimate in Gunung- kidul}

Gunungkidul Regency has 15 types of soils that spread throughout the topographic zones. The southern zone region is dominated by soil types of entisol, inceptisol, and oxisol. The middle zone consists of vertisol, entisol, alfisol, inceptisol, oxisol, and entis soil types. Meanwhile, in the northern zone the types of entisol, alfisol, inceptisol, vertisol, and oxixol types were spread (Figure 2). There are 12 commodity zone based on the suitability of agroecological zones (Figure 3). Zone IV/Wffe is a wetland agricultural zone where there is a source of irrigation water, but the zone has a limiting factor of drought risk especially during El Niño events, which results in a decrease of IP. Dry agroclimate zones on flat and undulating topography (IV/ Dve) and dry agroclimate on hilly land (II/Dffe) are predominantly the area up to $42 \%$ of the regency but limiting factor of plant growth separate the two zones. Zone IV/Dve has a limiting factor in the form of water availability and nutrient retention, while zone II/Dffe has a limiting factor in the form of root media, nutrient retention, and erosion hazard. The main agricultural commodities in Gunungkidul are maize, soybeans, and upland rice. The commodities were recommended to be planted in the two agroecological zones namely IV/Wffe and IV/Dfve. In addition, corn and soybean commodities can also be recommended in 4 other agro-ecological zones namely III/Dfle, III/Dffe, IV/Dej, and III/Dej. Information on the commodity zoning map with an alternative system of agricultural commodities in the Gunungkidul Regency is shown in Table 2.

\section{Characteristics of Climate and Season in Gunung- kidul}

The pattern of rainfall in the region is categorized as monsoonal type, covering two seasonal zones (ZOM 141 and 142) (Figure 4). Seasonal zone (ZOM) is an area where the average rainfall pattern has a clear difference between the dry season and the wet season. Areas where the average rain pattern does not have a clear difference between the dry season and the rainy season are called Non-ZOM areas. The area of a ZOM area is not always the same as the area of a government administration area. Thus, one ZOM area can consist of several districts, and vice versa, one district can consist of several ZOM. The distribution of rainfall will determine the general cropping pattern in the region.

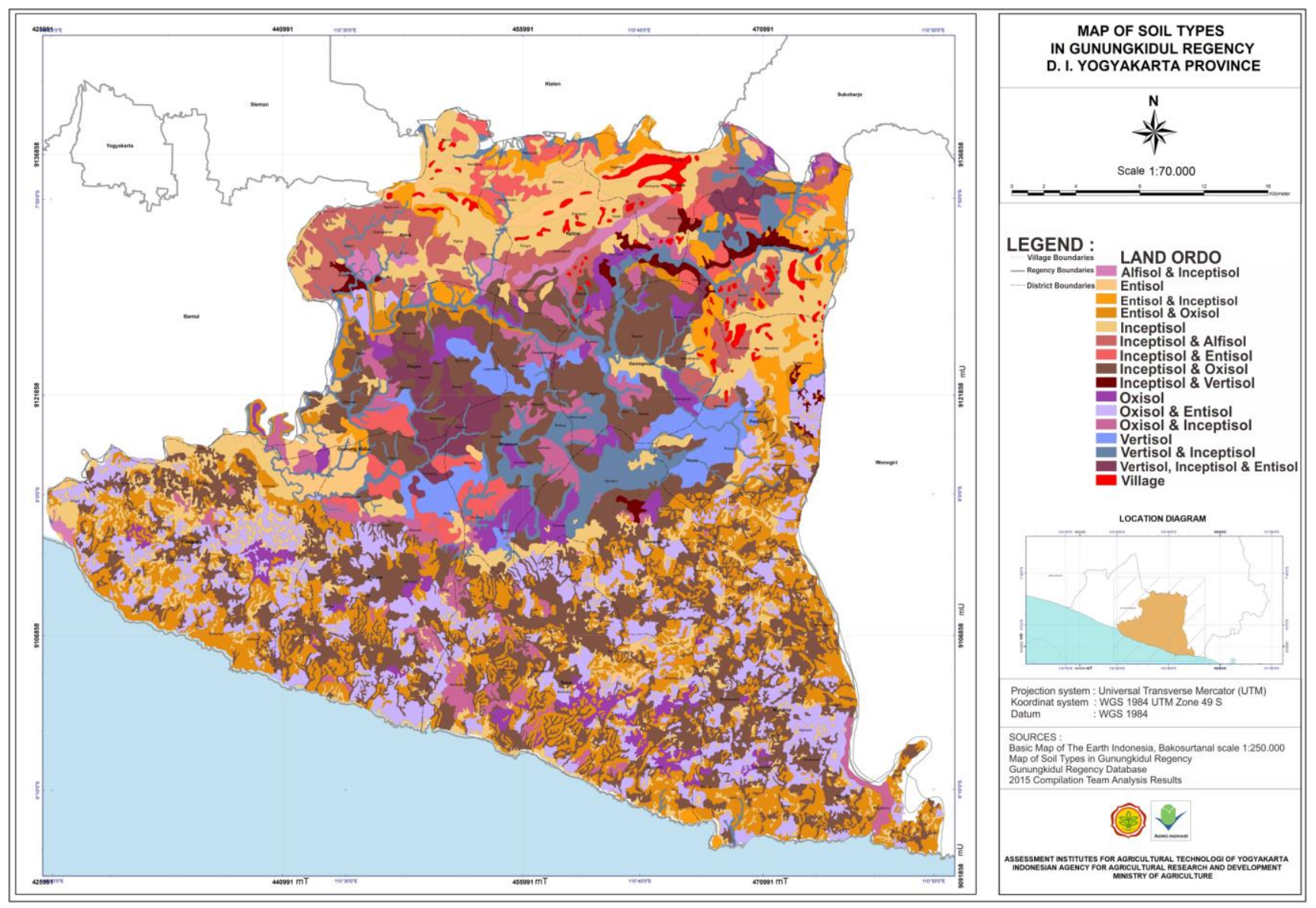

Figure 2. Map of soil types in Gunungkidul Regency (Source: Bekti et al., 2015). 


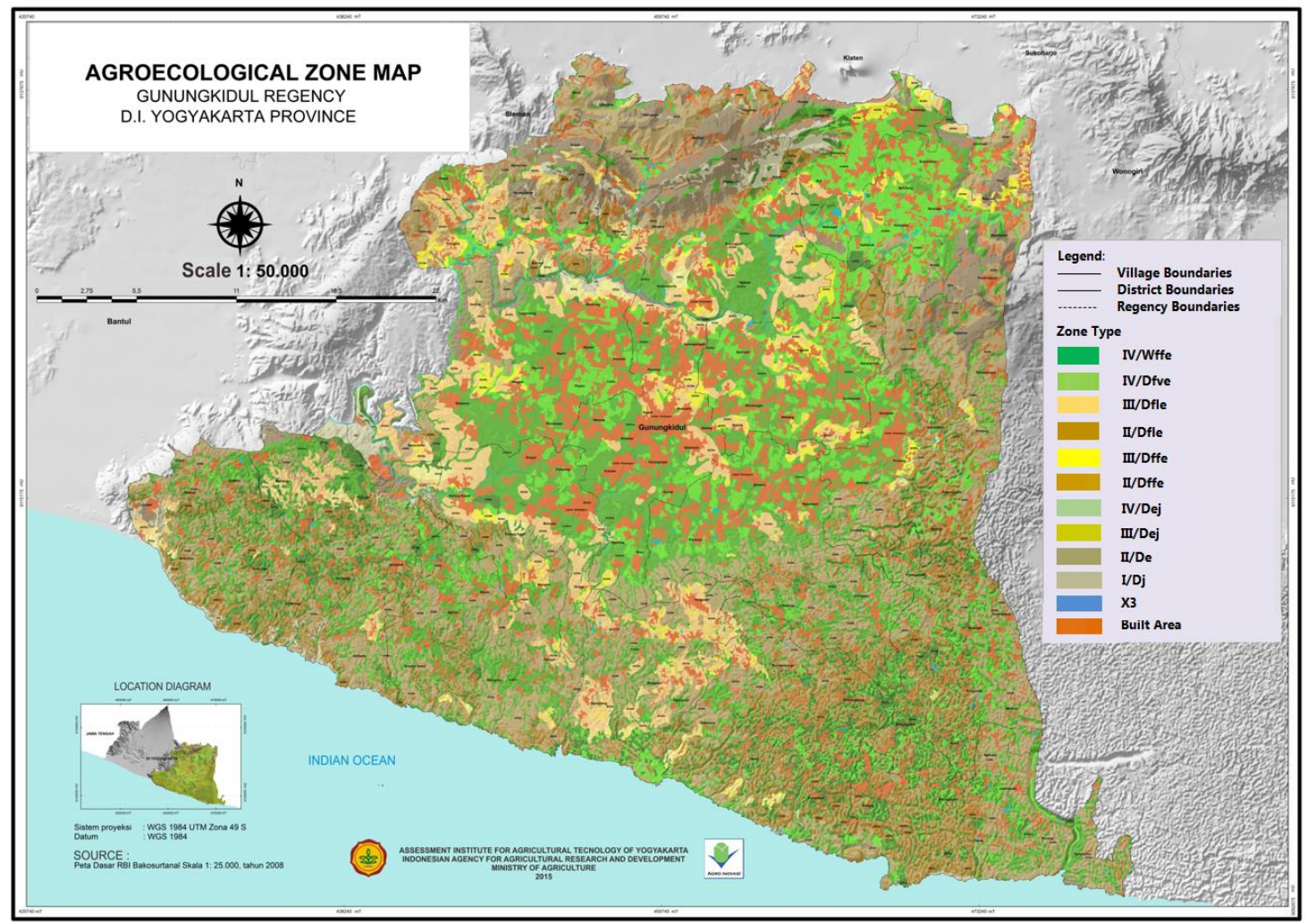

Figure 3. Agroecological zone map Gunungkidul Regency, D.I. Yogyakarta Province (Source: Bekti et al., 2015).

Generally, region with monsoonal type is more affected by extreme climate events, which will affect the water availability therefore the extreme climate event will change the beginning of the growing season (Pramudia et al., 2013). Typically, monsoonal type is characterized by a distinct pattern of rainfall between rainy and dry seasons (Azteria et al., 2008; Malik et al., 2016; Matsumoto et al., 2017; Verdon-Kidd et al., 2017).
Climate variability through ENSO will affect crop yield (Boer and Surmaini, 2020; Ismail and Chan, 2019; Qian et al., 2020), which potentially reduces rice IP. This reveals that the sufficiency of water (through rainwater or irrigation) will determine the choice of cropping pattern (Klemm and McPherson, 2017; Mohan and Patil 2018; Resiani and Sunanjaya, 2020; Sundaravalli and Geetha, 2016). In Gunungkidul, where water sources are

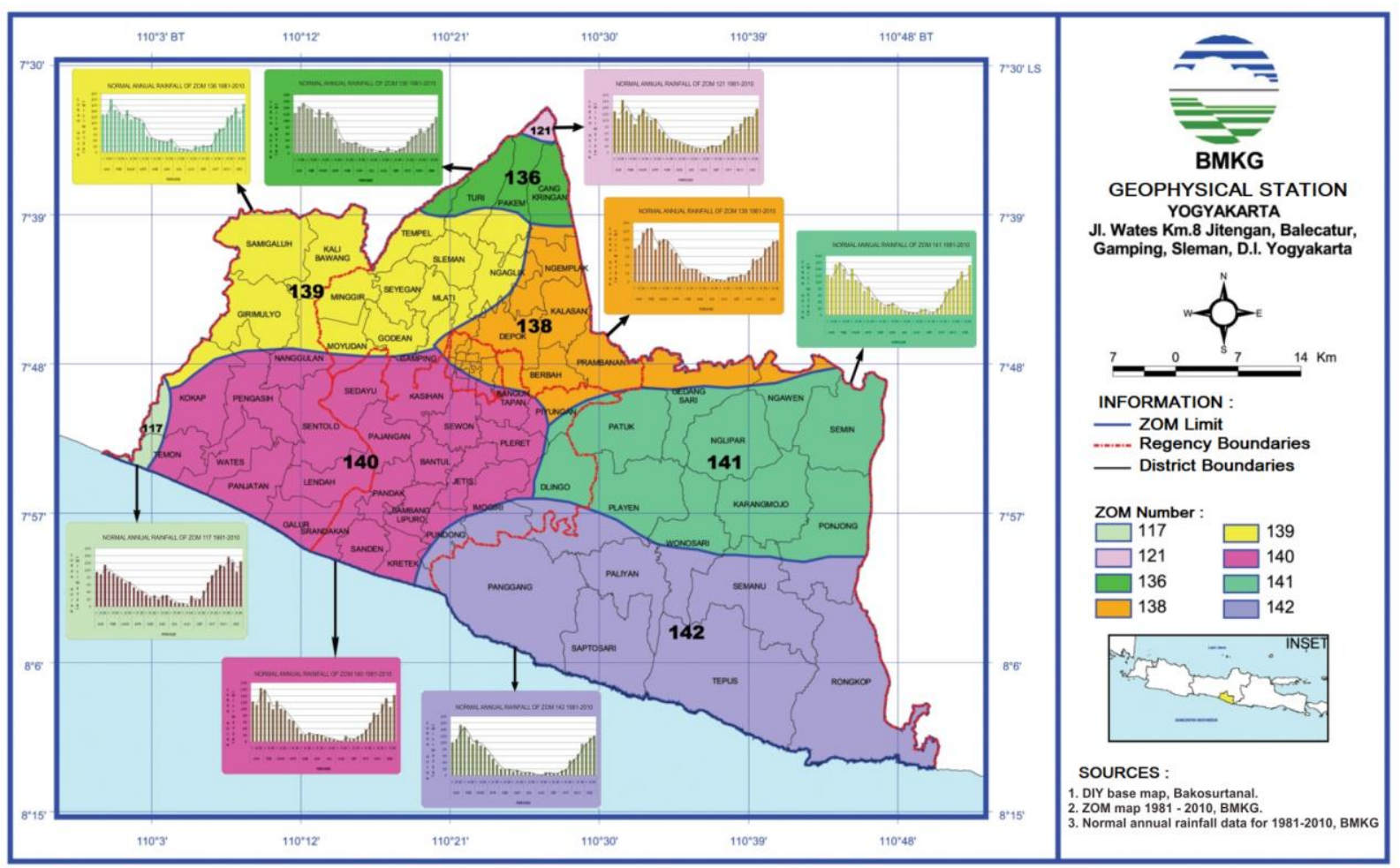

Figure 4. Rainfall pattern in DIY for each seasonal zonation map for period 1981-2010 (Source: BMKG-DIY, 2017). 
Table 2. Information on zonation with an alternative system of agricultural commodities in Gunungkidul Regency

\begin{tabular}{|c|c|c|c|}
\hline \multirow{2}{*}{ Zone } & \multirow{2}{*}{ Alternative system of agriculture commodities } & \multicolumn{2}{|c|}{ Areal expansion } \\
\hline & & ha & $\%$ \\
\hline \multicolumn{4}{|c|}{ Wetland agriculture, food crops, horticulture, annual crops/plantations } \\
\hline IV/Wffe & $\begin{array}{l}\text { Rice, corn, soybeans, peanuts, cassava, sweet potatoes, srikaya, } \\
\text { durian, rambutan, guava, sapodilla, avocado, papaya, banana, and } \\
\text { petai }\end{array}$ & 15,567 & 10.5 \\
\hline \multicolumn{4}{|c|}{ Dry land agriculture, food crops, horticulture, annual crops/plantations } \\
\hline IV/Dfve & $\begin{array}{l}\text { Upland rice, corn, soybeans, peanuts, cassava, sweet potatoes, } \\
\text { vegetable tomatoes, spinach, sapodilla, srikaya, durian, guava, } \\
\text { cashew, rambutan, avocado, papaya, petai, and banana }\end{array}$ & 31,405 & 21.1 \\
\hline \multicolumn{4}{|c|}{ Dry land agriculture, food crops, annual crops/plantations, animal feed forages } \\
\hline III/Dfle & $\begin{array}{l}\text { Peanuts, soybeans, sweet potatoes, cassava, corn, upland rice, } \\
\text { legumes, setaria, elephant grass, petai, sapodilla, srikaya, durian, } \\
\text { guava, rambutan, avocado, coconut, and cashew nuts }\end{array}$ & 11,280 & 7.6 \\
\hline II/Dfle & $\begin{array}{l}\text { Rambutan, petai, sapodilla, srikaya, durian, guava, cashew, cocoa, } \\
\text { elephant grass, legume, setaria, acacia, sengon, mahogany, teak, } \\
\text { pine, and eucalyptus }\end{array}$ & 12,540 & 8.4 \\
\hline \multicolumn{4}{|c|}{ Dry land agriculture, food crops, horticulture, annual crops/plantations } \\
\hline III/Dffe & $\begin{array}{l}\text { Srikaya, avocado, sapodilla, durian, guava, rambutan, papaya, } \\
\text { banana, petai, cashew, coconut, vegetable tomato, spinach, peanut, } \\
\text { soybean, sweet potato, cassava, upland rice, and corn }\end{array}$ & 3,143 & 2.1 \\
\hline II/Dffe & $\begin{array}{l}\text { Sawo, petai, srikaya, durian, guava, rambutan, cocoa, avocado, teak, } \\
\text { pine, acacia, sengon, mahogany, and eucalyptus }\end{array}$ & 32,018 & 21.6 \\
\hline \multicolumn{4}{|c|}{ Annual crops/plantations, dry forest land } \\
\hline IV/Dej & $\begin{array}{l}\text { Cocoa, teak, pine, acacia, sengon, mahogany, eucalyptus, cassava, } \\
\text { sweet potato, soybean, and corn }\end{array}$ & 9,973 & 6.7 \\
\hline III/Dej & $\begin{array}{l}\text { Cocoa, teak, pine, acacia, sengon, mahogany, eucalyptus, cassava, } \\
\text { sweet potato, soybean, and corn }\end{array}$ & 1,616 & 1.1 \\
\hline II/De & Cocoa, teak, pine, acacia, sengon, mahogany, and eucalyptus & 7,644 & 5.1 \\
\hline \multicolumn{4}{|c|}{ Dry forest land } \\
\hline I/Dj & Teak, pine, acacia, sengon, mahogany, and eucalyptus & 2,405 & 1.6 \\
\hline \multicolumn{4}{|c|}{ River/lake/body of water } \\
\hline X3 & River/lake/other body of water & 517 & 0.3 \\
\hline \multicolumn{4}{|l|}{ Built area } \\
\hline & Road, settlement, built area & 20,428 & 13.8 \\
\hline & Total & 148,536 & 100.0 \\
\hline
\end{tabular}

available two- or three-times planting season a year (IP 200 or IP 300) is possible. On other hand, area without having water sources (IP 100) may still possible to increase the IP by building water infrastructure. The mean rainfall of Gunungkidul Regency is in a range of $1,955-2,105 \mathrm{~mm}_{\text {year }}{ }^{-1}$. Based on the Oldeman classification, the regency has 4-6 wet months (> $100 \mathrm{~mm}$ month $^{-1}$ ) and dry months $<4$ per year, therefore it belongs to the C3-D3 agroclimate zone. On average, the planting season about 6-8 months. The rainfall intensity varies across agroclimate zones in Gunungkidul, although they have the same monsoonal rainfall type. The rainy season lasts from late October/early
November to late May/early June, while the dry season lasts from late June/early July to late September/early October (Figure 4).

\section{RESULTS AND DISCUSSIONS}

Scenarios to increase IP based on planting area extension and rice production in the rainfed field

\section{Determination of cropping patterns based on rainfall condition}

Figure 5 shows some alternative cropping patterns based on rainfall variability in Gunungkidul region. The alternatives 1 and 2 may suitable for normal and La Niña climate conditions. In planting period I and 
II (MT-I and MT-II), the amount of rainwater is sufficient to grow a rice two times (IP 200), and planting period III (MT-III) can be utilized to plant secondary crops with additional pumping water wells. On other hand, the cropping pattern 3 (alternative 3 ) can be applied when El Niño occurs or if the beginning of the rainy season delays around one month (about 3 or 4 ten-days).

In this condition, the amount of rainwater is limited, therefore we proposed in MT-I to plant early mature-rice (<95 days), while in MT-II and MT-III we proposed secondary crops (palawija) with the addition of pumping wells. In Gunungkidul, the farmers usually apply the alternative 4 as follows: MT-I plants rice once a year (IP 100), MT-II plants secondary crops, and MT-
III is fallow period. It is expected that the construction of water infrastructures, for instance with pumping wells, can increase IP in rainfed field. IP 200 or IP 300 means that farmers plant and harvest rice two or three times a year on the same landscape. The application of IP in rainfed field is expected to increase harvest times to be double from the current field area. In its implementation there are four key supporting factors the success of rice IP (BB-Padi, 2009), namely: (i) the use of seeds of very early mature-rice varieties (90-104 days) such as Dodokan, Silugonggo, Inpari 1, and Inpari 19; (ii) integrated pest and disease control (IPM); (iii) integrated nutrient management, and (iv) site-specific with efficient crop management and harvesting.

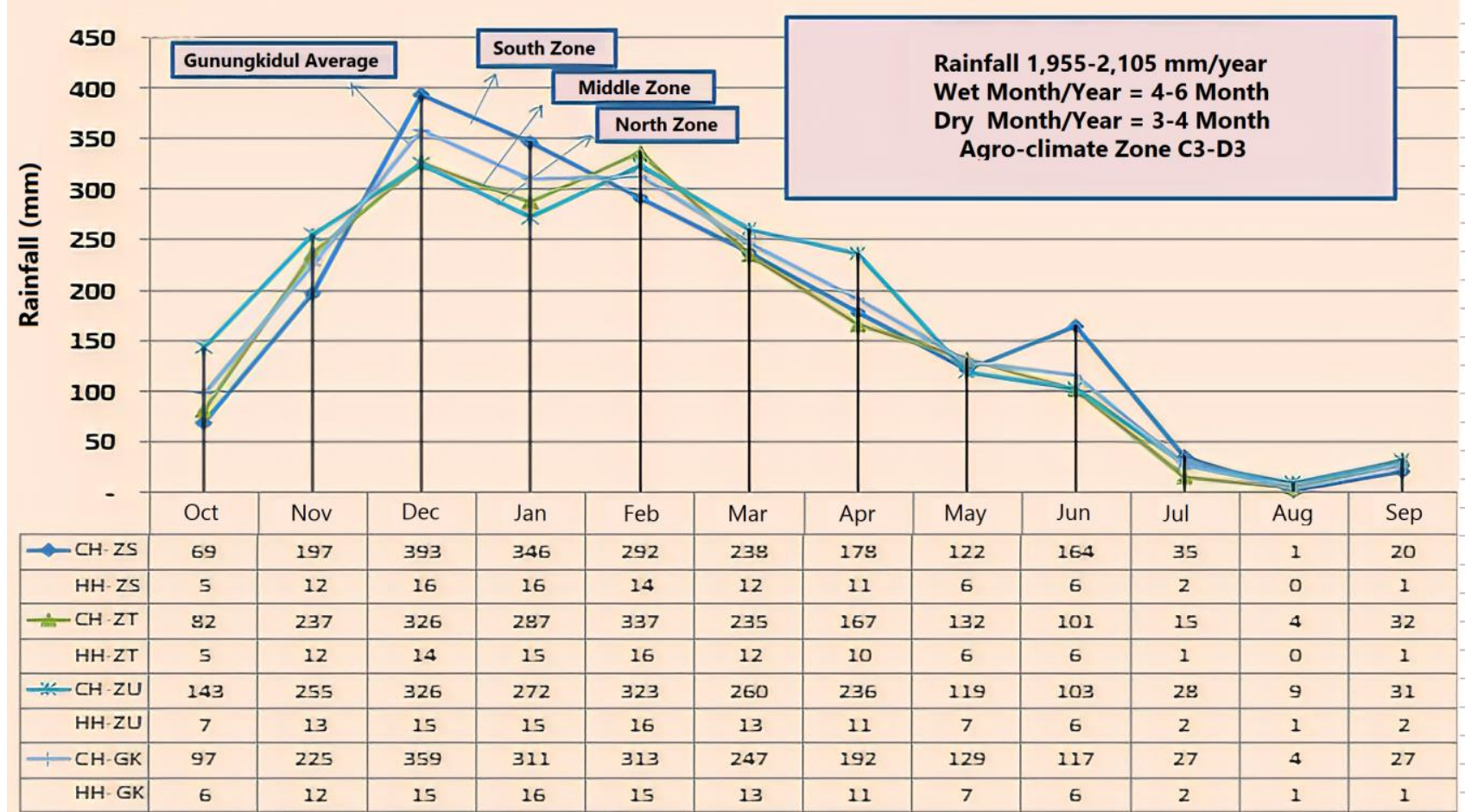

\begin{tabular}{|c|c|c|c|c|c|c|c|}
\hline Cropping Pattern 1 & $\mathbf{T}$ & $\begin{array}{l}\text { MT-I upland rice, Palawija } \\
\text { (Soybean, Corn, Cassava) }\end{array}$ & $\begin{array}{l}\text { WS } \\
15 \\
\text { days }\end{array}$ & $\begin{array}{l}\text { MT-II Palawija (Corn, Soybean, } \\
\text { Peanut, Shorghum), Vegetables }\end{array}$ & $\begin{array}{l}\text { MT-III Palawija (Corn, Soybean, } \\
\text { Peanut, Shorghum), Vegetables, } \\
\text { Tobacco (need a pump well) }\end{array}$ & $\begin{array}{l}\text { No } \\
\text { plant }\end{array}$ & $\mathbf{T}$ \\
\hline Cropping Pattern 2 & $\mathbf{T}$ & \multicolumn{2}{|c|}{$\begin{array}{l}\text { MT-I upland rice (direct Seeding- } \\
\text { harvest } 1 \text { age } 10 \text { days) }\end{array}$} & $\begin{array}{l}\text { MT-II Upland rice (harvest age } \\
90-100 \text { days) }\end{array}$ & \multirow{2}{*}{$\begin{array}{l}\text { MT-II Palawija (Corn, Soybean, } \\
\text { Peanut, Shorghum), Vegetables, } \\
\text { Tobacco (need a pump well) }\end{array}$} & \multirow{2}{*}{\multicolumn{2}{|c|}{$\begin{array}{l}\text { No } \\
\text { plant }\end{array}$}} \\
\hline & & & $\begin{array}{l}\text { WS } \\
15 \\
\text { days }\end{array}$ & & & & \\
\hline
\end{tabular}

\begin{tabular}{|l|c|c|l|l|}
\hline $\begin{array}{l}\text { Cropping Pattern } 3 \\
\text { (30-40 days late } \\
\text { rain) }\end{array}$ & No plant & T & $\begin{array}{l}\text { MT-I Upland rice (direct Seeding- } \\
\text { harvest age 110 days) }\end{array}$ & $\begin{array}{l}\text { MT-II Palawija (Corn, Soybean, Peanut, } \\
\text { Shorghum) }\end{array}$ \\
\hline
\end{tabular}

\begin{tabular}{|c|c|c|c|c|c|}
\hline $\begin{array}{l}\text { Cropping Pattern } 4 \\
\text { (Existing) }\end{array}$ & $\mathbf{T}$ & $\begin{array}{l}\text { MT-I Upland rice (direct Seeding-h } \\
120-125 \text { days), Corn, Soybean }\end{array}$ & arvest age & $\begin{array}{l}\text { MT-II Palawija (Corn, Soybean, } \\
\text { Peanut, Shorghum) }\end{array}$ & MT-III no plant \\
\hline 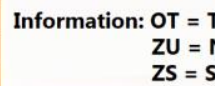 & $\begin{array}{l}\text { rillage } \\
\text { North Z } \\
\text { south Z }\end{array}$ & $\begin{array}{l}\text { CH = Rainfall HH = Rainy day } \\
\text { Zone } \mathrm{GK}=\text { Gunungkidul Regency } \\
\text { Zone } \quad \mathrm{ZT}=\text { Middle Zone }\end{array}$ & $\begin{aligned} M T & =G r o \\
W S & =W e\end{aligned}$ & $\begin{array}{l}\text { Ning season / Planting period } \\
\text { seeding early in time }\end{array}$ & \\
\hline
\end{tabular}

Figure 5. Alternative choices of cropping patterns according to rainfall distribution in the Gunungkidul Regency (processed from: BPS-Gunungkidul, 2017). 
Development Rice IP requires the following aspects (Supriatna, 2012) namely: (a) technical aspects including very early superior varieties (VUSG), wet seeding early in time, use of machinery, the introduction of decomposers and monitoring of plant disease pests, (b) economic aspects including the efficiency of production costs, production levels, and an income higher than existing (IP100) and grain price stability, (c) institutional aspects including optimization of farmer groups, microfinance support (capital, markets), provision of required technology, and government policies that support the sustainability of rice. To increase an IP index, some requirements must be met firstly. For instance IP 200, the targeted location must meet the following requirements: (i) the planting period is 3 months per season; (ii) there are potential local water sources such as field wells, electric wells; (iii) cultivation activities are carried out carefully such as land management and application of wet seeding early in time and (iv) the same planting period on a landscape level, to minimize pest and disease attacks. During the El Niño, strategy to choose and determine the superior varieties of rice that adaptive to various levels of drought vulnerability is needed, therefore it will minimize the risk of crop failure. Recommendations of of superior rice varieties on various levels of drought vul-

Table 3. The recommended superior rice varieties at various levels of drought vulnerability

\begin{tabular}{|c|c|c|}
\hline Criteria & Vulnerability Rate & Variety Recommendation \\
\hline \multirow{5}{*}{ DROUGHT } & Secure & $\begin{array}{l}\text { Inpari 1, Inpari 10, Inpari 13, Inpari 14, Inpari } 15 \text {, Inpari 16, Inpari 18, Inpari } \\
\text { 19, Inpari 20, Inpari } 38 \text {, Inpari 39, Inpari 40, Inpari } 41 \text {, Situ Patenggang, } \\
\text { Limboto, Batutegi, Situ Bagendit }\end{array}$ \\
\hline & Rather Vulnerable & $\begin{array}{l}\text { Inpari 1, Inpari 10, Inpari 13, Inpari 18, Inpari 19, Inpari 20, Inpari 38, Inpari } \\
\text { 39, Inpari 40, Inpari } 41 \text {, Situ Patenggang, Limboto, Batutegi, Situbagendit, } \\
\text { Inpago } 10\end{array}$ \\
\hline & Moderate Vulnerable & $\begin{array}{l}\text { Inpari 10, Inpari } 13 \text {, Inpari } 18 \text {, Inpari } 19 \text {, Inpari } 20 \text {, Inpari } 38 \text {, Inpari 39, Inpari } \\
\text { 40, Inpari } 41 \text {, Situ Patenggang, Limboto, Situbagendit, Inpago } 10\end{array}$ \\
\hline & Vulnerable & $\begin{array}{l}\text { Inpari 10, Inpari 18, Inpari 39, Inpari 40, Inpari } 41 \text {, Situ Patenggang, Limboto, } \\
\text { Batutegi, Situbagendit, Inpago 7, Inpago 8, Inpago } 10\end{array}$ \\
\hline & Very Vulnerable & $\begin{array}{l}\text { Inpari } 10 \text {, Inpari } 18 \text {, Inpari } 19 \text {, Inpari } 38 \text {, Inpari } 39 \text {, Inpari } 40 \text {, Inpari } 41 \text {, Situ } \\
\text { Patenggang, Limboto, Batutegi, Situbagendit, Inpago } 8 \text {, Inpago } 10\end{array}$ \\
\hline
\end{tabular}

Source: Modern Integrated Katam (Las et al., 2017)

nerability are presented in Table 3. In the MT-I, farmers usually plants rice (IP 100), therefore a strategy to increase IP should focus on MT- II and MT-III.

The following strategies may apply to MT-II in rainfed field:

a. The use of forecasting information on the onset and the end of the rainy season and dry season from the Meteorological Climatology and Geophysics Agency (BMKG);

b. Determination of the beginning of the rice growing season through the Modern Integrated Planting Calendar (a modern integrated KATAM) which is combined with local wisdom (Pranata Mangsa). KATAM is a tool that provide a spatial and tabular information on seasonal prediction, planting season, cropping pattern, potential planting area, flood and drought-prone areas, pest and disease attacks, recommendation on the dosage usage and fertilizer requirements, and recommendation on agricultural machinery based on prediction of climate variability and climate change (Las et al., 2017).

c. Accelerating soil tillage with 2- or 4-wheel tractors and should be done immediately after harvest time in MT-I. Soil tillage is an act of reversing, cutting, destroying, and leveling the soil. Soil tillage aims to improve soil conditions for root penetration, water infiltration and air circulation (aeration), prepare the land for surface irrigation, and eliminate crop residues that interfere with plant growth (Chakraborty et al., 2017; Fangueiro et al., 2017). Minimum (limited) soil processing is sufficient tillage by maintaining the remaining crop residue still above the surface of the land. The level of tillage depth and soil treatment systems affect enzymatic activity. The minimum tillage system can increase the activity of the urease enzyme and has the highest content of microbial biomass (C-biomass) (Mikanová et al., 2009). On other hand, a maximum land processing defines as the implementation of tillage as much as possible by holding plowing twice and harrow twice.

d. The use of superior short-lived and droughttolerant varieties (95-108 days) (Table 2). Previous studies revealed that the introduction of superior varieties on rainfed field can substantially increase rice productivity and farmers' income as shown by high benefit-cost ratio (Srihartanto et al., 2016).

e. The use of direct seed planting applications (Tabela) in MT-I, wet seeding early in time in MT-II, as well as the use of young seedlings ( 15 days after seedling). 
In accelerating the process of planting rice in rainfed field MT-I, direct seed planting techniques were done. One research showed that the use of Inpari 17 with 15-day after seedling had higher rice productivity than that of 20-day after seedling (Napisah and Ningsih, 2014).

f. Irrigation on a critical period by utilizing existing water sources (well fields/pumping wells/electric wells). Rice plants grow and develop well on soils that contain enough nutrients with soil moisture levels maintained at the field capacity. Any disturbances on the balance of nutrients and water will interfere plant growth and plant productivity (Abdou et al., 2016; Nouri et al., 2016).

g. Development program through social assistance to farmers and the introduction to technological innovation by demonstration plots of rice cultivation. For instance, the application of technological packages such as the Jajar Legowo Super Rice (Jarwo Super), Larikan Padi Gogo Super (Largo Super), and the intercropping system for rice-cornsoybean-sorghum (Turiman Pajalesho). Farmers play an active role in the process of empowering the program so that they are expected to be able to increase the knowledge, skills, and attitudes of farmers to become independent and willing to adopt technological innovations that are applied.

\section{Potency of water resources and determination of water infrastructure construction}

Models of surface irrigation system that are suitable for rainfed field among others:

a) Flooding. This system is carried out on the relatively flat ground by flowing water at a point until the water has been inundating the surface for some time. The land is divided into smaller sections and bounded by ditches so that the inundation through the ditches, which enables the distribution of water more uniform;

b) Rainwater harvesting techniques. This technique is carried out as an effort to optimize the excess rainwater for utilization during the dry season. Various techniques have been tried to collect rainwater to be stored in the rooting zone or temporarily collected as surface water and distributed during the dry season. In arid and semi-arid regions, many micro-relief modification techniques have been applied such as half-moon dykes, dead-end trenches or sediment pits, the contour's ridge system, tied ridging or boxed ridges, zoned tillage, and reservoirs (Miljković et al., 2019; Zhang et al., 2019). At the farmer level, rainwater harvesting can be done by making a reservoir. Farmers build reservoirs individually depending on the irrigated crop area. For example, for the needs of secondary crops with an area of 0.5 ha; reservoir needed has a dimension of length $10 \mathrm{~m}$, width $5 \mathrm{~m}$, and a depth of 2.5-3 m;

c) Level basin system. This system is very similar to the system of rice fields where the flat planting area is bound by water retaining dikes. The calculated irrigation water then be flowed through pipes into the planting area. At the time of submergence and surface shrinkage, water by itself will be distributed to fill the pores of the soil.

During period of less rainfall as in MT-II, the use of existing water sources needs to be optimized. Irrigation water is given when the physiological conditions of rice plants experience drought, which is indicated by rolling rice leaves. In this condition, the irrigation is needed until the condition of the flooded soil is as high as $\pm 5 \mathrm{~mm}$. Supposed electric pumping well with discharge of 2.5 liter second $^{-1}$ can irrigate 0.1 ha of land for 10 operational hours, for 1 ha rice as much of 100 hours are needed or equal to 10-days work. The greater the water discharge, the wider the area that can be irrigated. The limitation of operating hours for electric wells by 10 hours a day aims to keep the durability of electric well. Based on experience, one electric well can meet the water requirements of rice plants covering an area of 3-4 ha in one growing season.

An optimal use of water sources in Gunungkidul Regency has the potential to increase planting area, harvested area, as well as rice production and productivity. In 2016 and 2017, identification surveys of water sources and infrastructures were performed with team of researchers, BPP officers, local village officers, and farmers (Poktan/Gapoktan) in all sub-districts in Gunungkidul Regency. The sub-districts surveyed included: (i) the northern zone (Batur Agung), namely Gedangsari, Nglipar (Figure 6a and 6b), Semin, Ngawen, Patuk; (ii) the central zone (Ledok Wonosari), namely Playen, Wonosari, Karangmojo (Figure $6 c$ and $6 d$ ), Semanu, Ponjong; and (iii) the southern zone (Gunung Sewu), namely Girisubo, Rongkop, Tanjungsari, Tepus, Paliyan, Purwosari, and Saptosari.

Data collection was performed on each survey location by considering the potential and type of the nearest water sources and the impacted area. The survey was conducted by identifying and verifying water sources for agriculture, determining water structures and the budget needed, and taking into account the targeted area to increase IP. All data were collected to recapitulate the existing and the targeted IPs; and the types of the proposed water infrastructures at all survey locations. Water infrastructures include pumping/electricity wells, pipes for irrigation waterways, tertiary-secondary irrigation waterways, storage 

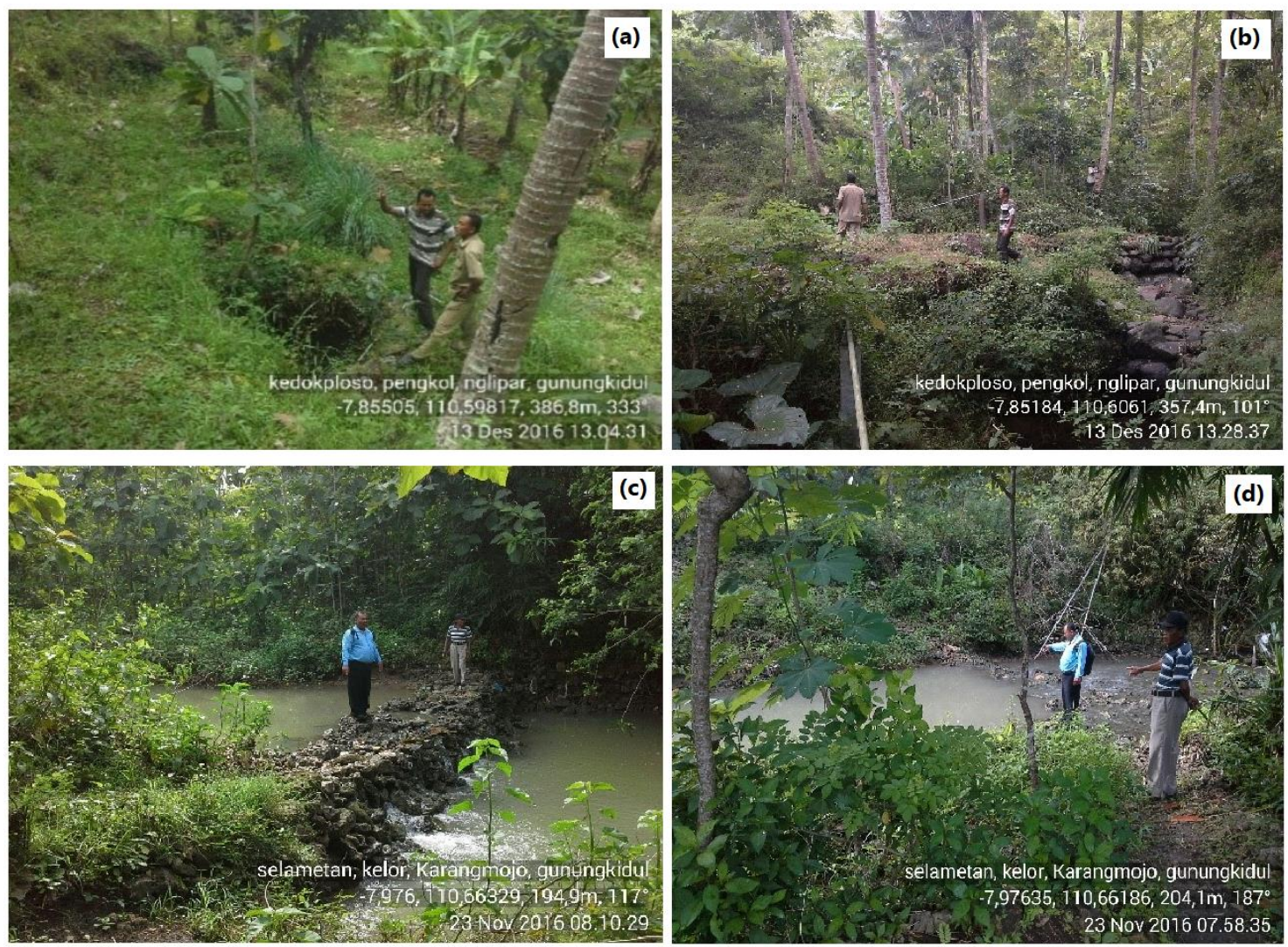

Figure 6. Survey and discussions on water sources with farmers and field officers (PPL) in Nglipar, Gunungkidul (a and b). In this sub-district, several water infrastructures were required to increase the rice crop index (IP) with a new 5-ha paddy field. Perennial water springs are available in this sub-district. Survey and discussions on a perennial river water source in Selametan, Kelor, Karangmojo, Gunungkidul (c and d). This location requires a trench dam with a pump system, which can provide water for 10 ha service area. By building this dam, an increased IP to IP 200 is expected.

tanks or water dividers, ditch dams, and reservoirs.

The results of the survey-interview showed that by constructing water infrastructure facilities and infrastructure will have a positive impact on the potential increase in rice IP from 100 to 200 and IP 200 to 300 in the Gunungkidul rainfed field (Table 4). The development of rice IP will work with the support of aquaculture technology and the construction of water infrastructures. In the northern zone (Batur Agung), Patuk sub-district has a potency of IP 200, with a harvested area of 122 ha and an increased production by $11 \%$. If we proposed IP 300 , the production will increase by $9,2 \%$ (Table 4). Generally, IP 200 will have a higher rice production than IP 300 . For instance, in Nglipar IP 200 increase the rice production by $9.17 \%$, whereas only $2.43 \%$ in IP 300 . A similar result was observed in Ngawen and Semin sub-districts.

In the middle zone (Ledok Wonosari), the harvested area and rice production have the same pattern as in the northern zone. The development of IP 200 was reported having higher yields comparing to the IP 300. The results were observed in Semanu, Ponjong, Karangmojo, Wonosari, and Playen subdistricts. The southern zone (Gunung Sewu) is not suitable to develop IP 300 . Some sub-districts may still possible to plant rice twice (IP 200), such as in Paliyan and Tepus sub-districts. But, other sub-districts are only possible for IP 100. The potential for IP development as previously discussed assumed that the level of rice productivity is similar to the previous season. Potency of harvested area in Gunungkidul through IP $200(2,111$ ha) is higher than IP 300 (687 ha) with a rice production of 10,058 tons (up $5.10 \%$ ) and 3,294 tons (up 1.67\%), respectively. This situation will be able to increase national production to support and maintain national rice self-sufficiency.

\section{CONCLUSIONS}

Determination of the beginning of the planting season in the rainfed field can adopt a combine of the Modern Integrated Planting Calendar (KATAM) and the forecast of the start of the rainy season. As many of 2,111 ha may available for the development of IP 200, which potentially increase the rice production of 10,058 tons (an increase of 5.10\%). For development of IP 300, the rainfed field only covers area of 687 ha with a potential production of 3,294 tons ( $1.67 \%$ increase). Further identification and verification are needed regar- 


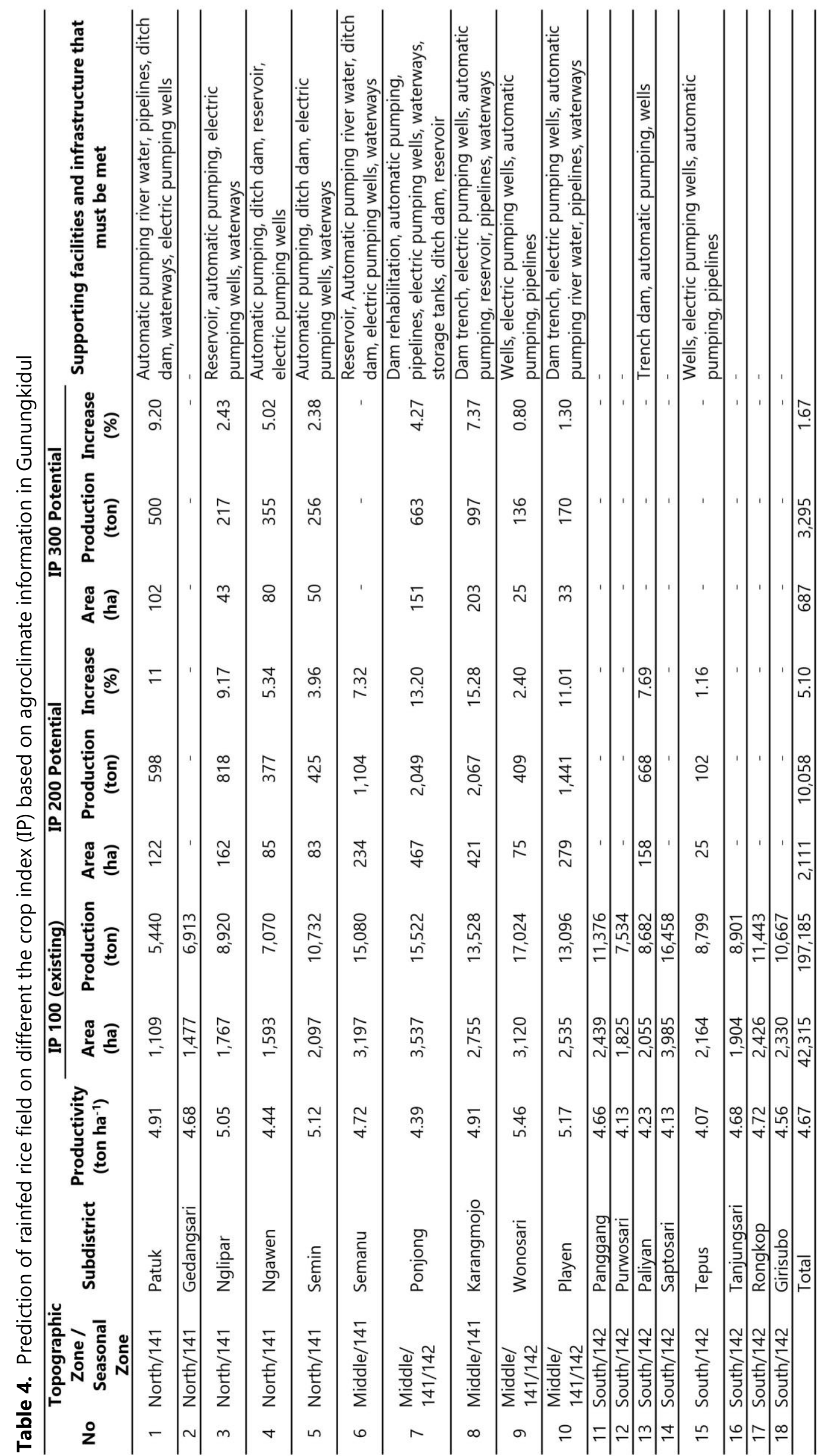


ding the potency of water sources. This will determine which types of water infrastructure are appropriate that must be provided for support the deve-lopment of IP and the national rice self-sufficiency.

\section{ACKNOWLEDGEMENTS}

The authors would like to thank the Modern Integrated Planting Calendar (KATAM TERPADU) task force team of Daerah Istimewa Yogyakarta and the field officers for their assistance and cooperation.

\section{REFERENCES}

Abdou, G., Ewusi-Mensah, N., Nouri, M., Tetteh, F.M., Safo, E.Y., Abaidoo, R.C., 2016. Nutrient release patterns of compost and its implication on crop yield under Sahelian conditions of Niger. Nutr Cycl Agroecosyst 105, 117-128. https://doi.org/10.1007/s10705-016-9779-9

Adamowicz, M., Szepeluk, A., 2016. Support to young farmers as part of agricultural policy of the European Union. Problems of Agricultural Economics.

Anwarudin, O., Sumardjo, S.A., Fatchiya, A., 2018. A review on farmer regeneration and its determining factors in Indonesia. International Journal of Progressive Sciences and Technologies (IJPSAT) 10, 218-230.

Azteria, V., Effendy, S., Hermawan, E., 2008. Pemanfataan Data Equatorial Atmosphere Radar (Ear) Dalam Mengkaji Terjadinya Monsun Di Kawasan Barat Indonesia (the Valuable of Equatorial Atmosphere Radar (Ear) Data to Study Monsoon in the West Area Indonesia). Agromet 22, 160-173.

BB-Padi, 2009. Pedoman umum Peningkatan IP Padi 400. Peningkatan Produksi Padi melalui Pelaksanaan IP Padi 400. Balai Besar Penelitian Tanaman Padi. Badan Penelitian dan Pengembangan Pertanian. Kementerian Pertanian.

Bekti, U.B., Iswadi, A., Mulyadi, Budiono, Damasus Riyanto, Subagiyo, Srihartanto, E., 2015. AEZ II : Penyusunan Peta Pewilayahan Komoditas Berdasarkan Zona Agroekologi (Zae) Skala 1 : 50.000 Kabupaten Gunungkidul Daerah Istimewa Yogyakarta, Laporan Akhir tahun 2015. D.I.Yogyakarta.

Bhatta, G.D., Ojha, H.R., Aggarwal, P.K., Sulaiman, V.R., Sultana, P., Thapa, D., Mittal, N., Dahal, K., Thomson, P., Ghimire, L., 2017. Agricultural innovation and adaptation to climate change: empirical evidence from diverse agroecologies in South Asia. Environ Dev Sustain 19,
497-525. https://doi.org/10.1007/s10668-0159743-x

BMKG-DIY, 2017. Buletin Badan Meteorologi Klimatologi dan Geofisika Stasiun Klimatologi Mlati Edisi September 2017. Badan Meteorologi Klimatologi dan Geofisika Daerah Istimewa Yogyakarta, D.I.Yogyakarta.

Boer, R., Surmaini, E., 2020. Economic benefits of ENSO information in crop management decisions: case study of rice farming in West Java, Indonesia. Theoretical and Applied Climatology 139, 1435-1446.

Boonlertnirun, S., Boonraung, C., Suvanasara, R., 2017. Application of chitosan in rice production. Journal of Metals, Materials and Minerals 18.

Boonwichai, S., Shrestha, S., Babel, M.S., Weesakul, S., Datta, A., 2019. Evaluation of climate change impacts and adaptation strategies on rainfed rice production in Songkhram River Basin, Thailand. Science of The Total Environment 652, 189-201. https://doi.org/10.1016/j.scitotenv.2018.10.20 1

BPS-DIY, 2017. Provinsi Daerah Istimewa Yogyakarta Dalam Angka 2017. Badan Pusat Statistik Provinsi D.I. Yogyakarta, Yogyakarta.

BPS-Gunungkidul, 2017. Gunungkidul Dalam Angka 2017. Badan Pusat Statistik-Kabupaten Gunungkidul.

Bravo-Ureta, B.E., Higgins, D., Arslan, A., 2020. Irrigation infrastructure and farm productivity in the Philippines: A stochastic Meta-Frontier analysis. World Development 135, 105073.

Budhi, M.K.S., Yasa, I.N.M., Darma, K., 2017. Impacts of development of population and conversion of agricultural land on food security (rice) in Bali, Indonesia. International Journal of Economics, Commerce and Management 12, 634-643.

Chakraborty, D., Ladha, J.K., Rana, D.S., Jat, M.L., Gathala, M.K., Yadav, S., Rao, A.N., Ramesha, M.S., Raman, A., 2017. A global analysis of alternative tillage and crop establishment practices for economically and environmentally efficient rice production. Scientific Reports 7, 1-11. https://doi.org/10.1038/s41598-017-09742-9

Dahal, B.M., Raut, N., Gurung, S., Sharma, C.M., Kayastha, R., Shrestha, A., Gautam, B., 2018. Changing trends in cultivation practices and adoption of climate adaptive farming in Eastern Nepal. Sustainable Agriculture Research 7, 52-62.

Estiningtyas, W., Boer, R., Buono, A., 2009. Analisis Hubungan Curah Hujan dengan Kejadian Banjir dan Kekeringan pada Wilayah dengan Sistim USAhatani Berbasis Padi di Propinsi Jawa Barat 
(Analysis Of Relationship Between Rainfall And Flood AS Well AS Drought Events On Area With Rice... Agromet 23, 11-19.

Faisal, F., Mustafa, M., Yusuf, Y., 2019. A Review of Technology Innovation in Increasing Rice Production. Agrotech Journal 4, 75-82.

Fangueiro, D., Becerra, D., Albarrán, Á., Peña, D., Sanchez-Llerena, J., Rato-Nunes, J.M., LópezPiñeiro, A., 2017. Effect of tillage and water management on GHG emissions from Mediterranean rice growing ecosystems. Atmospheric Environment 150, 303-312. https://doi.org/10.1016/j.atmosenv.2016.11.02 0

Flor, R.J., Singleton, G., Casimero, M., Abidin, Z., Razak, N., Maat, H., Leeuwis, C., 2016. Farmers, institutions and technology in agricultural change processes: outcomes from Adaptive Research on rice production in Sulawesi, Indonesia. International Journal of Agricultural Sustainability 14, 166-186. https://doi.org/10.1080/14735903.2015.10669 76

Gremmen, B., Blok, V., Bovenkerk, B., 2019. Responsible Innovation for Life: Five Challenges Agriculture Offers for Responsible Innovation in Agriculture and Food, and the Necessity of an Ethics of Innovation. J Agric Environ Ethics 32, 673-679. https://doi.org/10.1007/s10806-01909808-w

Hong-xing, X., Ya-jun, Y., Yan-hui, L., Xu-song, Z., Junce, T., Feng-xiang, L., Qiang, F., Zhong-xian, L., 2017. Sustainable management of rice insect pests by non-chemical-insecticide technologies in China. Rice Science 24, 61-72.

Ikeura, H., Phongchanmixay, S., Chomxaythong, A., Matsumoto, N., Kawamura, K., Homsengchanh, L., Inkhamseng, S., 2019. Variation in lowland rice yield and its determinants in a rainfed area in Savannakhet Province, Laos. Paddy Water Environ 17, 121-130. https://doi.org/10.1007/s10333-019-00704-7

Ismail, N.W., Chan, S.M., 2019. Impacts of the El NiñoSouthern Oscillation (ENSO) on Paddy Production in Southeast Asia. Climate and Development 0 , 1-13. https://doi.org/10.1080/17565529.2019.16731 41

Jamil, A., Satoto, Sasmita, P., Suharna, 2016. Deskripsi Varietas Unggul Baru Padi. Kementerian Pertanian, Badan Penelitian dan Pengembangan Pertanian.

Kathpalia, J., Tyagi, R., Kumari, V., 2018. Perceived constraints related to inputs and production by direct seeded rice growers in Kurukshetra district. International Journal of Education and Management Studies 8, 280-282.

Klemm, T., McPherson, R.A., 2017. The development of seasonal climate forecasting for agricultural producers. Agricultural and Forest Meteorology 232, 384-399. https://doi.org/10.1016/j.agrformet.2016.09.00 5

Kumar, A., Mahapatra, S.K., Lal, T., Yadav, R.P., Singh, S.K., 2017. Land Evaluation for Land Use Planning towards Sustainable Crop Production: A Case Study of Chhata tehsil in Mathura District, Uttar Pradesh, India. International Journal of Current Microbiology and Applied Sciences 6, 859-870.

Kumar, V., Naresh, R.K., Kumar, Sumit, Kumar, Sunil, Kumar, A., Gupta, R.K., Rathore, R.S., Singh, S.P., Dwivedi, A., Tyagi, S., Mahajan, N.C., 2018. Efficient Nutrient Management Practices for Sustaining Soil Health and Improving RiceWheat Productivity: A Review.

Las, I., Syahbuddin, H., Runtunuwu, E., 2017. Katam Terpadu Modern versi 2.5. D.I.Yogyakarta.

Lv, Z., Zhu, Y., Liu, X., Ye, H., Tian, Y., Li, F., 2018. Climate change impacts on regional rice production in China. Climatic Change 147, 523-537. https://doi.org/10.1007/s10584-018-2151-0

Malik, N., Bookhagen, B., Mucha, P.J., 2016. Spatiotemporal patterns and trends of Indian monsoonal rainfall extremes. Geophysical Research Letters 43, 1710-1717. https://doi.org/10.1002/2016GL067841

Materu, S.T., Shukla, S., Sishodia, R.P., Tarimo, A., Tumbo, S.D., 2018. Water use and rice productivity for irrigation management alternatives in Tanzania. Water 10, 1018.

Matsumoto, J., Wang, B., Wu, G., Li, J., Wu, P., Hattori, M., Mori, S., Yamanaka, M.D., Ogino, S., Jun-Ichi, H., 2017. An overview of the Asian Monsoon Years 2007-2012 (AMY) and multi-scale interactions in the extreme rainfall events over the Indonesian maritime continent, in: The Global Monsoon System: Research and Forecast. World Scientific, pp. 365-385.

May, D., Arancibia, S., Behrendt, K., Adams, J., 2019. Preventing young farmers from leaving the farm: Investigating the effectiveness of the young farmer payment using a behavioural approach. Land Use Policy 82, 317-327. https://doi.org/10.1016/j.landusepol.2018.12.0 19

Mikanová, O., Javůrek, M., Šimon, T., Friedlová, M., Vach, M., 2009. The effect of tillage systems on some 
microbial characteristics. Soil and Tillage Research 105, 72-76.

Miljković, J.Ž., Pantić, M., Bezbradica, L., 2019. Sustainable Land Use Planning Solutions for Water Supply Reservoirs in Serbia. European Journal of Sustainable Development 8, 18-18. https://doi.org/10.14207/ejsd.2019.v8n4p18

Mohan, P., Patil, K.K., 2018. Deep Learning Based Weighted SOM to Forecast Weather and Crop Prediction for Agriculture Application. International Journal of Intelligent Engineering and Systems 11, 167-176.

Mulyaqin, T., 2020. The Impact of El Niño and La Nina on Fluctuation of Rice Production in Banten Province. Agromet 34, 34-41. https://doi.org/10.29244/j.agromet.34.1.34-41

Napisah, K., Ningsih, R., 2014. Pengaruh Umur Bibit Terhadap Produktivitas Padi Varietas Inpari 17, in: Inovasi Teknologi Pertanian Spesifik Lokasi. Banjarbaru, pp. 127-132.

Nouri, M., Homaee, M., Bannayan, M., Hoogenboom, G., 2016. Towards modeling soil texture-specific sensitivity of wheat yield and water balance to climatic changes. Agricultural Water Management 177, 248-263. https://doi.org/10.1016/j.agwat.2016.07.025

Pramudia, A., Estiningtyas, W., Susanti, E., Suciantini, 2013. Fenomena dan Perubahan Iklim Indonesia serta Pemanfaatan Informasi Iklim untuk kalender Tanam; Dalam: Kalender Tanam Terpadu (Penelitian, Pengkajian, Pengembangan dan Penerapan). IAARD Press, Jakarta.

Qian, Y., Zhao, J., Zheng, S., Cao, Y., Xue, L., 2020. Risk assessment of the global crop loss in ENSO events. Physics and Chemistry of the Earth, Parts A/B/C 116, 102845. https://doi.org/10.1016/j.pce.2020.102845

Resiani, N.M.D., Sunanjaya, I.W., 2020. The Efficiency of Water in Supporting Local Wisdom and Food Sustainability in Subak Sange, Bali Indonesia. Agromet 34, 67-74. https://doi.org/10.29244/j.agromet.34.2.67-74

Soerono, 2008. Kawasan Karst di Gunungkidul dan Kearifan lokal. Bulletin Tata ruang ISSN; 19781571, Edisi Nopember-Desember 2008. Sub Bagian Tata usaha direktorat Jenderal Penataan Ruang.

Srihartanto, E., Mulyadi, Sugeng, W., 2016. Kajian Budidaya Padi Melalui Varietas Unggul Padi Dan Rekomendasi Pemupukan Pada Lahan
Tadah Hujan Inceptisols Gunungkidul, D.I. Yogyakarta. Presented at the Prosiding seminar Nasional Hasil Peneltiian Pertanian VI 2016, Fakultas Pertanian Universitas Gadjah Mada.

Sundaravalli, N., Geetha, A., 2016. A Study \& Survey on Rainfall Prediction And Production of Crops Using Data Mining Techniques. International Research Journal of Engineering and Technology (IRJET) 3, 1269-1274.

Supriatna, A., 2012. Meningkatkan indeks pertanaman padi sawah menuju IP padi 400. Agrin 16.

Supriyadi, S., Rachmawati, S., Herawati, A., Purwanto, P., 2018. Soil quality assessment of the rainfed lowland ricefields under organic and conventional farming systems in Kaliwungu (Central Java). Polish Journal of Soil Science 51. https://doi.org/10.17951/pjss.2018.51.2.173

Surmaini, E., Susanti, E., Sarvina, Y., Syahputra, M.R., 2018. Development of Early Detection Method for Drought and Flood on Rice Paddy. Agromet 32, 81-92.

Tanko, Y., Kang, C.Y., Islam, R., 2019. Impact of Rural Infrastructure on Rice Productivity in Kano State, Nigeria. European Academic Journal 7, 286-311.

Valarmathi, M., Muthukumar, M., Rahman, H., Sasikala, R., 2019. Development of early maturing, high yielding, drought tolerant rice variety with superior grain quality through molecular breeding and its performance evaluation. Journal of Pharmacognosy and Phytochemistry 8, 338-346.

Verdon-Kidd, D.C., Hancock, G.R., Lowry, J.B., 2017. A 507-year rainfall and runoff reconstruction for the Monsoonal North West, Australia derived from remote paleoclimate archives. Global and Planetary Change 158, 21-35. https://doi.org/10.1016/j.gloplacha.2017.09.00 3

Zeng, D., Tian, Z., Rao, Y., Dong, G., Yang, Y., Huang, L., Leng, Y., Xu, J., Sun, C., Zhang, G., Hu, J., Zhu, L., Gao, Z., Hu, X., Guo, L., Xiong, G., Wang, Y., Li, J., Qian, Q., 2017. Rational design of high-yield and superior-quality rice. Nature Plants 3, 1-5. https://doi.org/10.1038/nplants.2017.31

Zhang, J., Li, S., Dong, R., Jiang, C., Ni, M., 2019. Influences of land use metrics at multi-spatial scales on seasonal water quality: A case study of river systems in the Three Gorges Reservoir Area, China. Journal of Cleaner Production 206, 76-85.

https://doi.org/10.1016/j.jclepro.2018.09.179 